\title{
IMPACT OF UREA FERTILIZER ON GORWTH AND BIOCHEMICAL COMPOSITION OF SOME AQUATIC PLANTS
}

\section{Mary Ghobrial}

Botany Department of Hydrobiology, National Institute of Oceanography and Fisheries, Kayet Bay, Alexandria, Egypt.

\section{(Received November 13, 1999)}

Key words: Aquatic plants, crude protein, fat content, yield, urea.

\section{ABSTRACT}

This study has been conducted to evaluate the effect of varying 1 concentrations of urea fertilizer on the growth, protein, fat and water content of five aquatic plants, in aquaculture system. These plants were cultured in glass basins outside the laboratory in tap water and they received doubling doses of urea fertilizer $(1,2,4,6,8$ and $16 \mathrm{~g})$ per $30 \mathrm{~L}$ medium at three days intervals. The media were changed before receiving the following inoculum and the excess yields were harvested. Potamogeton crispus, $P$. pectinatus and Ceratophyllum demersum could withstand urea concentrations up to $533 \mathrm{mg} / \mathrm{L}$, while Polygonum amphibium could survive at $133 \mathrm{mg} / \mathrm{L}$, but Azolla filiculoides died at the same concentration. Crude protein increased, generally during the experiment, in all test plants except in $P$. crispus that showed wide fluctuations. Fat content decreased in all plants by the end of the experiments, but water content fluctuated slightly between increases and decreases during the experiment.

\section{INTRODUCTION}

All waters used for irrigation contain various amounts of soluble or dissolved salts. Some of the individual constituents of the dissolved salts may be beneficial to plant growth and other are harmful. The variability and complexity of many effluents make it difficult to assess 
their impact on aquatic organisms in the receiving water. However, little is known about the responses of aquatic plants to various combinations or varying concentrations of chemicals.

Thus, the effects of many chemicals on aquatic plants under laboratory test conditions, should be tested. This, although aquatic plants in the receiving water may be subjected to many more stresses than those tested under laboratory conditions. Urea contains approximately 45 percent nitrogen and is the most commonly available and lowest cost nitrogenous fertilizer. Urea is the most efficient form of nitrogen supply to terrestrial crops, but its volatility in water and its elevating effect on $\mathrm{pH}$ makes it problematic for hydroponic applications. Skillicorn et al. (1991) suggested that $4.5 \mathrm{~kg}$ urea/ha/day were enough to sustain a yield of 1,000 $\mathrm{kg} / \mathrm{ha} /$ day of fresh duckweed.

Many authors have attempted to utilize or determine the potential usefulness of aquatic plants that has cost nothing to grow, and which is relatively easy to harvest because floating or submerged plants are usually fragile. On the other hand, technology required for production, harvesting and processing has not yet been well developed.

Skillicorn et al. (1991) suggested that aquatic plants would be important as a source of fish and poultry feed and simultaneously as a wastewater treatment process in selected areas of the Middle East, particularly in Egypt. they claimed also that, aquaculture systems are many times more productive than terrestrial agriculture and have the potential to increase protein production at rates similar to increases of terrestrial carbohydrate crops. In addition, the solid fraction of most aquatic plants has about the same quantity and quality of protein as soybean meal.

Limaza et al. (1984), tested some aquatic plants and decided that they contained more protein than corm. In addition, Dewanji (1993), indicated that leaf protein extracted from unwanted aquatic plants could 
Impact of urea fertilizer on growth and biochemical composition of some aquatic plants

be used for food / feed purposes. Even fibrous biproduct, left after the extraction of aquatic leaf proteins, could be utilized as additional feed for ruminants.

Van Hove and Leieune (1996) outlined the useful characteristics of Azolla, thus it can be utilized for rice production, as a green manure to supply feed for animals and fish, and a nitrogen fertilizer to improve soil structure.

However, growth of aquatic plants may well serve the dual function of extracting nutrients from wastewater effluents and producing animal feeds. The economic value of the harvested plants may totally or partially compensate for the cost of nutrient removal (Culley and Epps, 1973).

Several criteria considered in evaluating aquatic plants for the above purposes included selection of plants that; (a) could be easily harvested, (b) were low in water content, (c) had high protein content, (d) had low fiber content, (e) had extended growing and harvesting periods, (f) were non-toxic to humans and domestic stocks, (g) were capable to being processed. Some species of submerged, emerged and floating plants seem to fulfill some of the criteria. From them, Potamogeton pectinatus, P. cripus, Ceratophyllum demersum, Polygonum amphibium and Azolla filiculoides. The purpose of this research is to investigate the biomass production, of the 5 aquatic plants (submerged, emergent and floating) grown on water contaminated with urea fertilizer, and estimate the commercial possibilities of the test plants.

\section{MATERIALS AND METHODS}

Plant sample :

All plants were collected during the period between October (1998) and April (1999). Fresh plants were taken from Abis waterways, 
near Alexandria city, but away from waters receiving direct run-off from croplands. Occasionally pure stands of the test species were collected for the experiments. All samples were thoroughly washed with tap water. Fresh and young plants were used for the experiments.

The widespread species; the submerged Potamogeton pectinatus L., P. crispus L., Ceratophyllum demersum L., the free floating Azolla filiculoides and the emergent Polygonum amphibium were planted in glass basins (30L capacity) outdoors, on chlorine free tap water, (1g fresh plant/ L medium). Tap water left in big jars 3 days to get rid of chlorine.

\section{Experiment :}

To test the effect of nitrogen fertilizer on growth and internal composition (nitrogen and fat) of the plants. Different combinations of nitrogen in the form of urea fertilizer were added. All culture media were inoculated with urea concentrations of $1,2,4,8,16$ and $32 \mathrm{~g}$ urea fertilizer, at a period interval of 3 days. One gram urea contained $0.46 \mathrm{~g} \mathrm{~N}$. The whole media were changed every three days before receiving the following urea enrichment. Three replicates were used per species per treatment. The initial plant inoculum was maintained $(\mathrm{g} / \mathrm{L}$ medium) by harvesting the excess yield, which is considered as a growth indicator.

Anatysis

Fresh plant samples were weighed and then dried at $105^{\circ} \mathrm{C}$ for 24 hours. After complete dryness their weights were determined and the differences were calculated for water content. The dry samples were used for determination of total nitrogen and fat contents. Total nitrogen was determined after grinding the plant material and digestion with $\mathrm{K}_{2} \mathrm{Cr}_{2} \mathrm{O}_{7}$ / $\mathrm{H}_{2} \mathrm{SO}_{4}$ (Golterman et al., 1978). Fat content (ether extract) was determined using soxlett apparatus and petroleum ether was used as ogranic solvent (A.O.A.C., 1990). 
Impact of urea fertilizer on growth and biochemical composition of some aquatic plants

\section{RESULTS AND DISCUSSION}

The dry yield of Potamogeton crispus fluctuated between 0.113 and $0.310 \mathrm{~g} / \mathrm{g}$ initial and between 0.094 and $0.139 \mathrm{~g} / \mathrm{g}$ initial for $P$. pectinatus. Ceratophyllum demersum gave yield between 0.082 and $0.136 \mathrm{~g} / \mathrm{g}$ initial dry weight. It appeared that $P$. crispus outperformed the other two plants attaining highest biomass yield within 15 days incubation, but they all could withstand high $\mathrm{N}$-urea concentration in the substrate up to $533 \mathrm{mg} / 1$ medium. Higher $\mathrm{N}$-urea inoculum lead to disintigration of the three plants ( $P$. pectinatus, $P$. crispus and $C$. demersum) as shown in table 1.

Rogers and Breen (1980) mentioned that, nitrogen appeared in least supply during growth of $P$. crispus, and may have been limiting. In the current experiments enrichment of $\mathrm{N}$-urea fertilizer at concentration level of $133 \mathrm{mg} / 1$ proved to enhance growth of $P$. crispus with a biomass yield 2.5 times the initial plant inoculum. Higher $\mathrm{N}$-urea concentrations yield lower biomass. $P$. pectinatus and $C$. demersum needed lower nitrogen addition ( $33 \mathrm{mg} \mathrm{N}$-urea/ L) to increase their biomass production by about 1.2 times their initial inoculum. Higher $\mathrm{N}$-urea addition lead to slight but consequent decreases in their yield (Fig. 1).

Wijck et al. (1994) pointed out that $100 \mathrm{mg} \mathrm{N}$-urea improved biomass production of $P$. pectinatus, but $400 \mathrm{mg} \mathrm{N}$-urea yielded higher biomass. The previous authors tested the plant for $\mathrm{N}$-urea enrichment but in sediments used for plant growth. Thus, nitrogen was available for both roots and shoots. However, $P$. pectinatus grows mostly from tubers and can therefore establish itself rapidly, even in systems with a low nutrient . Additionally, the denitrifying capacity of epiphyton, on shoots of $P$. pectinatus, adapted to high nutrient loadings was about 100 times higher than that of epiphyton adapted to lower nutrient levels (Erikson and 
Weisner (1996). This could explain also, the adaptability of $P$. pectinatus to the $\mathrm{N}$-urea concentrations which reached $533 \mathrm{mg} / \mathrm{l}$ medium.

Goulder and Boatman (1971) showed that growth of $C$. demersum was affected by the nitrogen supply and good growth was obtained in experiments by adding nitrogen $(\sim 4 \mathrm{mgN} / \mathrm{L})$. $C$. demersum gave best yield at $33 \mathrm{mg} \mathrm{N}$-urea/ $\mathrm{L}$, but the yield was less pronounced by additional N-urea.

Polygonum amphibium is said to indicate low levels or the absence of pollution (Whitton, 1975), but it seemed that it could tolerate $\mathrm{N}$-urea levels up to $67 \mathrm{mg} / \mathrm{L}$. Higher concentration lead to a detach of the green leaves and wilting of the stems.

Concentration of $33 \mathrm{mg} \mathrm{N}$-urea enhanced Azolla filiculoides growth, but $67 \mathrm{mg} / \mathrm{L}$ lead to decreased growth accompanied by detach of its roots and $133 \mathrm{mg} / \mathrm{l}$ was lethal to the plant. These results were in accordance with Manna and Singh (1990) who indicated that increasing levels of urea nitrogen decreased the fresh biomass of Azolla spp.

Crude protein was variable in the 2 Potamogeton species and Ceratophyllum but consistantly higher than their initial in $P$. pectinatus and $C$. demerum ranging from 23.8 to $30.3 \%$ and from 25.3 to $39.8 \%$ respectively (Fig. 2). It decreased in $P$. crispus compared to its initial, after treatment, to a range from 23.3 to $36.2 \%$. Van Vierssen (1982) found a maximum nitrogen concentration of $4.1 \%$ (25.23\% protein) in $P$. pectinatus, but this was still lower than obtained in the present investigation. Also, Balley (1965) gave protein content $18.3 \%$ in Ceratophyllum sp. considering its commerical possibilities, as new additives which could improve the efficiency of feed demands.

Crude protein reached $19.41 \%$ in dry tissues of $P$. amphibium from $11.61 \%$. This values was less than given by Byers (1961) for Polygonum sp. used for protein extraction (24.13\%). Azolla protein 
Impact of urea fertilizer on growth and biochemical composition of some aquatic plants

increased slightly (from 22 to $24.94 \%$ ) after 6 days incubation period. Similar result was given by Kitoh and Shiomi (1991), who mentioned that urea addition in the medium resulted in an increase in nitrogen content in Azolla.

It is important to point out that it cannot be assumed that all nitrogen goes into protein, because there is non-protein nitrogen (amino acids) which may compose about $30 \%$ of the dry weight of aquatic plants (Culley and Epps, 1973).

The concentration of protein in both Potamogeton spp., Ceratophyllum demersum and Azolla filiculoides dry tissues compared favorably with that in many animal feeds (Alfalfa meal, yellow com, soybeans and wheat bran contained 20.0, 8.8, 37.0 and $14.5 \%$ crude protein respectively).

Fat content dropped in all test plants by the end of the experiments. Fat content in the initially used test plants represented respetcively; $0.71,0.55,0.37,5.5$ and $0.22 \%$ in $P$. crispus, $P$. pectinatus, $C$. demersum, $A$. filiculoides and $P$. amphibium. It dropped to $0.61,0.42$, $0.29,3.9$, and $0.23 \%$ respectively. Fat values in the tested plants were generally lower than those of animal feeds, with the exception of Azolla filiculoides. Compared with fat composition used in animal feeds (alfalfa meal, corn grass, soybean meal and wheat bran which contained 3.5, 3.8, 3.5 and $3.0 \%$ respectively), Azolla filiculoides showed favorable levels, even after exposure to pollution stress by urea fertilizer.

Water content of the different test plants did not exhibit pronounced variations. It varied from $86.4-89.5 \%, 88.9-90.6 \%$, 90.4$29.1 \%$ and from $83-86.6 \%$ in P.crispus, $P$. pectinatus, C. demersum and $P$. amphibium respectively, while very slight decrease in water content was observed in A. filiculoides (from 85.7 to $85.0 \%$ ). Joy (1969) reported 
values of 86 to $89 \%$ obtained in plants having poor growth rates. He suggested that the lower water content was caused by more starch in the plants, which may be an advantage because starch is a major source of energy in feedstuffs.

In conclusion, $\mathrm{N}$-urea could be a limiting factor for growth of some plants (Azolla and Polygonum) in waterways which may receive the agricultural drainage contaminated with urea fertilizer. On the other hand, these drainage water could be advantageous for other macrophytes growth, with extended growing and harvesting periods.

The present study also concluded that some of the test plants $(P$. crispus, $P$. pectinatus and $C$. demersum) had promising possibility for protein extraction and possible utility in manufacturing of food for fish and animals.

Aquatic plants farming can be a continuous process, requiring intensive management for optimum production. Harvested plant biomass can be used daily in its fresh form as fish feed or dried for use in other animal feeds.

\section{REFERENCES}

A.O.A.C. (1990) Official methods of analysis ot the Association of Official Analytical Chemists. $15^{\text {th }} \mathrm{Ed}$.

Balley, T. A.(1965) Commerical possibilities of dehydrated aquatic plants. Proceedings of the $18^{\text {th }}$ Annual Texas Nutrition Conference, 543551.

Byers, M.(1961) Extraction of protein from the leaves of some plants growing in Ghana. Journal Sci. Food Agric.,12: 20-30.

Culley, D. D. and Epps, E. A. (1973) Use of Duckweed for waste treatment and animal feed. Journal WPCF $\therefore, 45$ (2): 337-347. 
Impact of urea fertilizer on growth and biochemical composition of some aquatic plants

Dewanji, A. (1993) Amino acid decomposition of leaf proteins extracted from some aquatic weeds. J. Agric. Food. Chem. Washington, P. C.: American Chemical Society, . 41 (8): 1232-1236.

Erikson, P. G. and Weisner, S. E. B. (1996) Functional differences in epihytic microbial communities in nutrient- rich fresh water ecosystems: an assay of denitrifying capacity. Freshwater Biology, 36 (3): 555-562.

Golterman, H. L.; Clymo, R. S. and Ohnstad, M. A. H.(1978) Methods for physical and chemical analysis of fresh waters. FBP handbook. No. (8) $\left(2^{\text {nd }}\right.$ Ed.) Blackwell Sci. Pub., Oxford, 213pp.

Goulder, R. and Boatman, D. J.(1971) Evidence that nitrogen supply influences the distribution of a freshwater macrophyte, Ceratophyllum demersum. Journal Ecol., 59: 783-791.

Joy, K. W. (1969) Nitrogen Metabolism of Lemna minor. I. Growth Nitrogen Sources and Amino acid inhibition. Plant Physiol., 44: 845.

Kitoh, S. and Shiomi, N.(1991) Effect of mineral nutrients and combined nitrogen sources in the medium on growth and nitrogen fixation of the Azolla-Anabaena association. Soil Sci. Plant Nutr., 37 (3): 419-426.

Limaza, L. C.; Mc Dowell, L. R. and Marion, J. E.(1984) Utilization of aquatic plants Elodea canadensis and Hydrilla verticillata in laying hen diets. II. Macrominerals and microminerals. Nutr. Rep. Int. Stoneham, Mass: Butterworth, 39 (3) : 521-536.

Manna, A. B. and Singh, P. K. $(1990)$ Growth and nitrogen fixation of Azolla pinnata and Azolla caroliniana as affected by urea fertilizer and their influence on rice yield. Plant and Soil, 122 (2): 207-212. 
Rogers, K. H. and Breen, C. M. (1980) Growth and reproduction of Potamogeton crispus in a south African lake. Journal of Ecology, 68: 561-571.

Skillicorn, P.; Spira, W. and Journey, W.(1991) Duckweed Aquaculture. The world bank, Emena Technical Department. Technical Working Paper.

Van Hove, C. and Leiveune, A.(1996) Does Azolla have any future in agriculture? In Biological nitrogen fixation associated with rice production. International Symposium, Dhaka, Bangladesh.

Van Vierssen, W. (1982) The ecology of communities dominated by Zannichellia taxa in western Europe. III. Chemical ecology. Aquat. Bot.,14: 259-294.

Whitton, B. A.(1975) River Ecology, Studies in Ecology, Vol. 2: 106-128. Blackwell Scientific Publications, Oxford.

Wijck, C.; Grillas, P.; Jan de Groot, C. and Tan Ham, L.(1994) A comparison between the biomass production of Potamogeton pectinatus L. and Myriophyllum spicatum L. in the Camargue (Southern France) in relation to salinity and sediment characteristics. Vegetatio,113: 171-180. 
Impact of urea fertilizer on growth and biochemical composition of some aquatic plants

Table 1. Growth characteristics, dry matter yield, \% water content, $\%$ crude protein and \% Fat (ether extract) during the experiment in the different test plants, cultured outdoors in media enriched with different combinations of $\mathrm{N}$-urea.

\begin{tabular}{|c|c|c|c|c|c|c|}
\hline Plant species & \begin{tabular}{|c} 
Duration of \\
incubation \\
days
\end{tabular} & $\begin{array}{c}\text { N-urea } \\
\text { concentration } \\
\text { mg/ }\end{array}$ & $\begin{array}{l}\text { Dry weight } \\
\text { (g/g initial) }\end{array}$ & $\begin{array}{c}\% \text { water } \\
\text { content }\end{array}$ & $\begin{array}{l}\% \text { crude } \\
\text { protein }\end{array}$ & $\begin{array}{l}\% \text { fat } \\
\text { (ether } \\
\text { extract) }\end{array}$ \\
\hline \multirow{6}{*}{$\begin{array}{l}\text { Potamgeton } \\
\text { crispus }\end{array}$} & Start & - & 0.125 & 87.5 & 39.13 & 0.71 \\
\hline & 3 & 33 & 0.146 & 87.5 & 27.44 & N.E \\
\hline & 6 & 67 & 0.185 & 86.5 & 25.00 & N.E \\
\hline & 9 & 133 & 0.310 & 88.6 & 36.19 & N.E \\
\hline & 12 & 266 & 0.145 & 89.5 & 23.25 & N.E \\
\hline & 15 & 533 & 0.113 & 86.4 & 25.25 & 0.61 \\
\hline \multirow{6}{*}{$\begin{array}{c}P . \\
\text { pectinatues }\end{array}$} & Start & - & 0.113 & 88.7 & 16.75 & 0.55 \\
\hline & 3 & 33 & 0.139 & 88.9 & 25.00 & N.E \\
\hline & 6 & 67 & 0.115 & 90.1 & 30.32 & N.E \\
\hline & 9 & 133 & 0.129 & 88.9 & 28.37 & N.E \\
\hline & 12 & 266 & N.E. & N.E. & N.E. & N.E \\
\hline & 15 & 533 & 0.094 & 90.6 & 23.83 & 0.42 \\
\hline \multirow{6}{*}{$\begin{array}{l}\text { Ceratophyllum } \\
\text { demersum }\end{array}$} & Start & - & 0.109 & 89.1 & 23.75 & 0.37 \\
\hline & 3 & 33 & 0.136 & 90.4 & 25.28 & N.E \\
\hline & 6 & 67 & 0.135 & 91.4 & 39.79 & N.E \\
\hline & 9 & 133 & 0.117 & 91.6 & 30.90 & N.E \\
\hline & 12 & 266 & 0.093 & 92.1 & 27.70 & N.E \\
\hline & 15 & 533 & 0.082 & 91.8 & 33.24 & 0.29 \\
\hline \multirow{4}{*}{$\begin{array}{l}\text { Polygonum } \\
\text { amphibium }\end{array}$} & $\overline{\text { Start }}$ & - & 0.170 & 83.0 & 11.61 & 0.22 \\
\hline & 3 & 33 & 0.163 & N.E. & N.E. & N.E \\
\hline & 6 & 67 & 0.140 & N.E. & N.E. & N.E. \\
\hline & 9 & 133 & 0.136 & 86.6 & 19.41 & 0.23 \\
\hline \multirow{4}{*}{$\begin{array}{c}\text { Azolla } \\
\text { filiculoides }\end{array}$} & Start & - & 0.137 & 85.7 & 22.00 & 5.50 \\
\hline & 3 & 33 & 0.144 & 85.7 & 27.51 & N.E \\
\hline & 6 & 67 & 0.141 & 85.0 & 27.51 & N.E. \\
\hline & 9 & 133 & Distintigrate & - & $\cdots$ & 3.9 \\
\hline
\end{tabular}

N.E. not estimated because the dry yield was very small. 


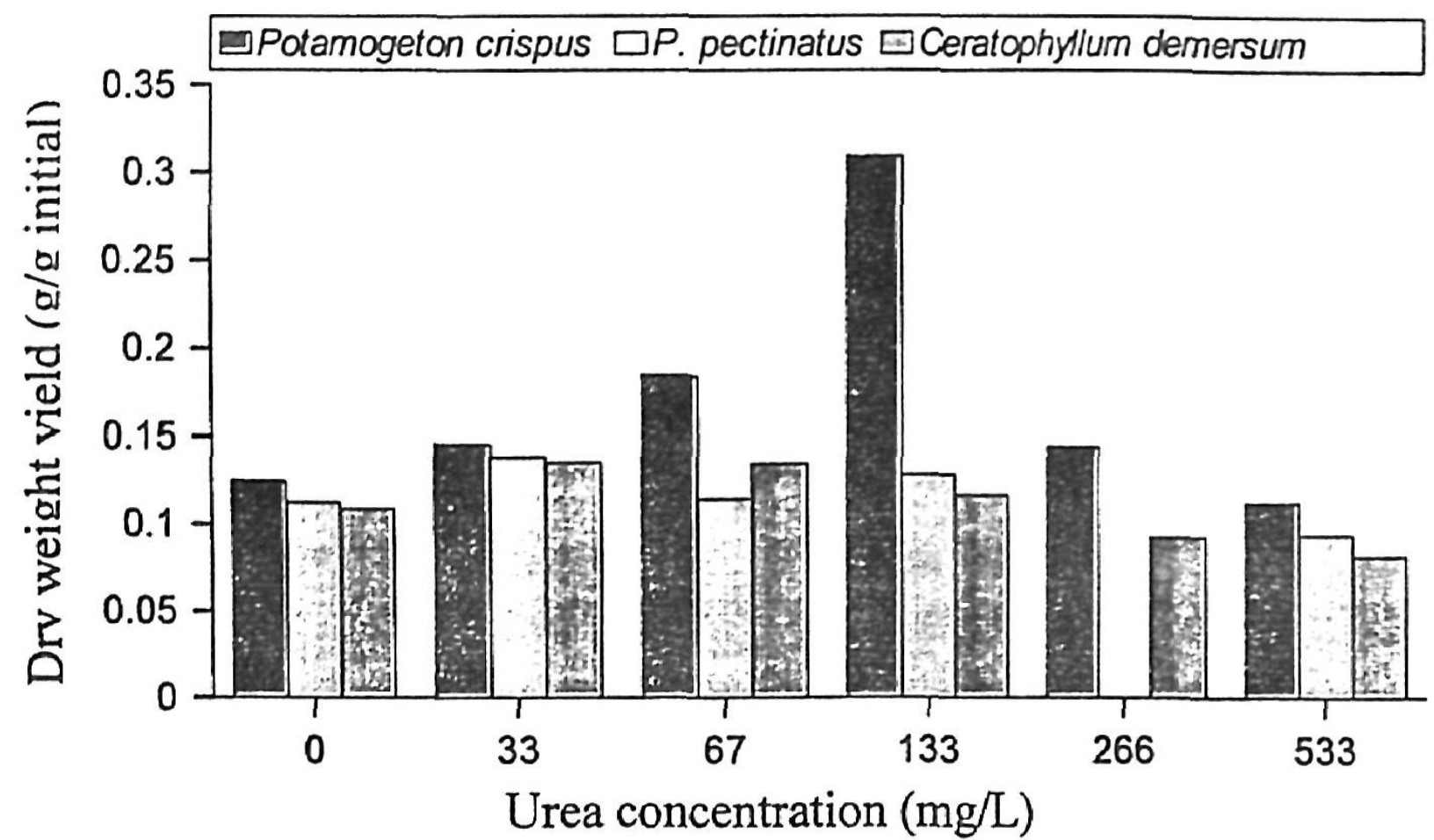

Fig. 1: Dry matter yield harvested during the experiment after enrichment with $\mathrm{N}$-urea fertilizer.

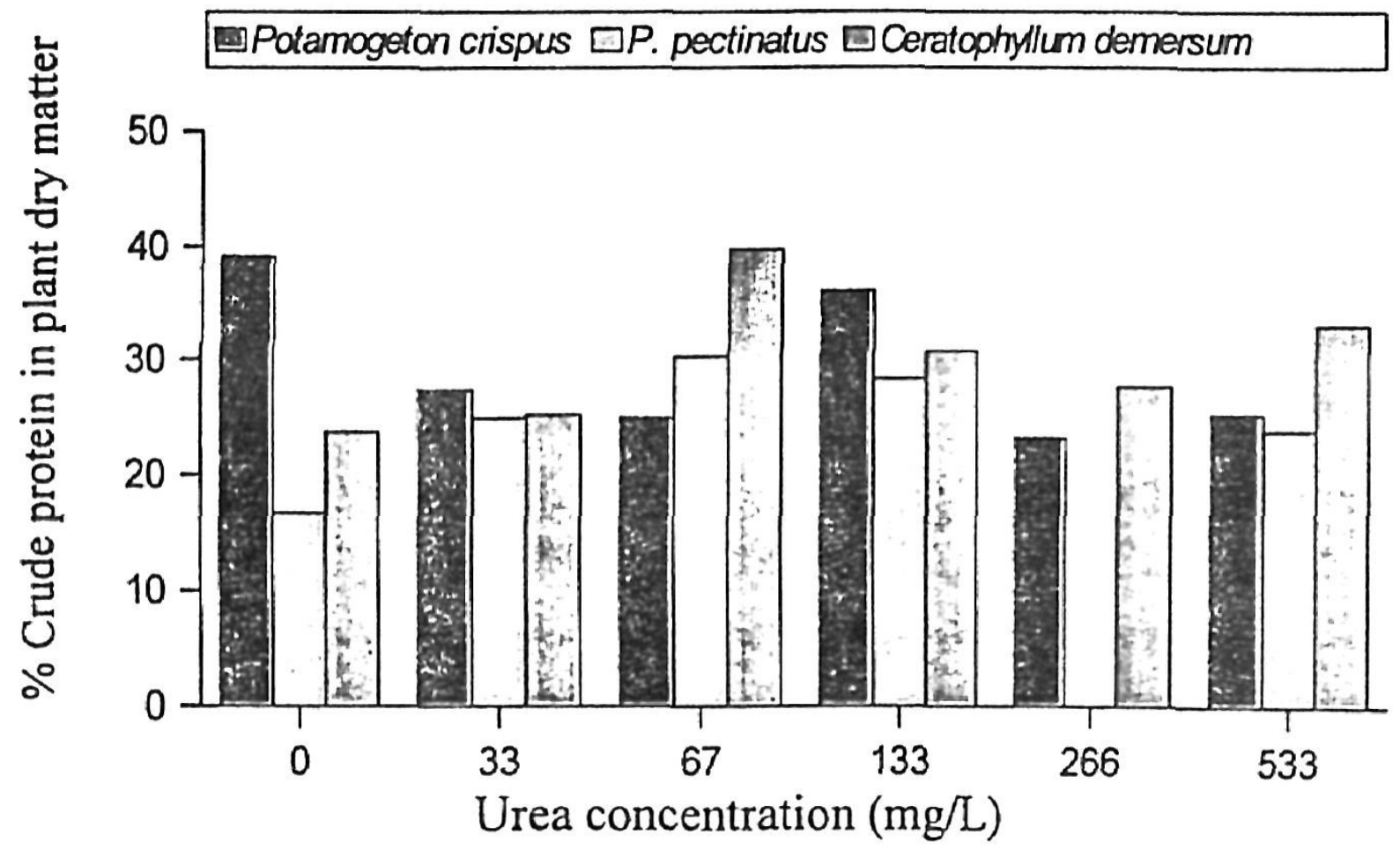

Fig. 2: Fluctuations in \% crude protein in the test plants as affected by variations in $\mathrm{N}$-urea concentrations. 